Bull. Chem. Soc. Ethiop. 2019, 33(2), 293-306.

ISSN 1011-3924

(c) 2019 Chemical Society of Ethiopia and The Authors

Printed in Ethiopia

DOI: https://dx.doi.org/10.4314/bcse.v33i2.10

\title{
PHYTOCHEMICAL INVESTIGATION AND EVALUATION OF ANTIMICROBIAL ACTIVITIES OF STEM BARK OF MORELLA SALICIFOLIA
}

\author{
Birhanu Gebriel Meniso ${ }^{1}$, Aman Dekebo Boru ${ }^{2 *}$ and Neelaiah Babu Ganjinaboyina ${ }^{1}$ \\ ${ }^{1}$ Department of Chemistry, Haramaya University, P.O. Box 138, Dire Dawa, Ethiopia \\ ${ }^{2}$ Department of Applied Chemistry, Adama Science and Technology University, P.O. Box 1888, \\ Adama, Ethiopia
}

(Received February 8, 2017; Revised March 22, 2019; Accepted March 29, 2019)

\begin{abstract}
The Morella salicifolia bark is used as a traditional medicine for the treatment of toothache, headache and stomachache in the eastern Ethiopia. The stem bark of the plant was sequentially extracted with: petroleum ether, chloroform and chloroform/methanol (1:1) using Soxhlet apparatus. Phytochemical screenings tests were conducted on of stem bark this plant extracts were performed on petroleum ether, chloroform and chloroform/methanol (1:1) crude extracts. The results showed presence of alkaloid, tannins, saponins, flavonoid, protein, and triterpenoids in the petroleum ether extract; alkaloid, tannin, flavonoid, protein, triterpenoid and absence of saponins chloroform extract; tannin, flavonoid, triterpenoid and absence of alkaloid, tannin, saponins and protein in the chloroform/methanol (1:1) extract. Volatile oil of the stem bark of plant was analyzed by GCMS and it constitute 14 compounds among which the major compounds were hexadecanoic acid methyl ester $(29.40 \%),(Z)-9$-octadecenoic acids and methyl ester $(28.64 \%)$. The volatile oil and crude extracts of the stem bark were tested in vitro for their antimicrobial activity by disk diffusion method. The highest activity was exhibited by volatile oil, $\mathrm{CHCl}_{3} / \mathrm{MeOH}$ (1:1) and petroleum ether extract against Shigela flexneri, Escherichia coli and Streptococcus agalactiae with an inhibition diameter of $21.66,17.66$ and $18.00 \mathrm{~mm}$, respectively.
\end{abstract}

KEY WORDS: Antimicrobial activity, Disk diffusion, Morella salicifolia, GC-MS analysis

\section{INTRODUCTION}

Herbal plants produce and contain a variety of chemical substances that act upon the body [1]. Herbal medicine is the oldest form of healthcare known system to mankind. The use of plants as medicines dates back before the written human history. Almost all countries in the world have an expertise concerned with the therapeutic properties of the local flora [2]. Many drugs commonly used today are of herbal origin. For example, about $25 \%$ of the prescriptions of drugs dispensed in the United States contain at least one active ingredient derived from plant material. Some are made from plant extracts; others are synthesized to mimic a natural plant compound. According to WHO report [3] 119 plant-derived pharmaceutical medicines, where by about $74 \%$ are used in modern medicine in many ways are correlated directly with their traditional uses as plant medicines by native cultures. Plant products have played an important role in the discovery of new therapeutic agents [4] since ancient times, for instance quinine obtained from Cinchona has been successfully used to treat malaria [5].

Morella salicifolia (Hochst. Ex A. Rich.) Verdc. \& Polhill belongs to the flowering plants in the family of Myretaceae. It contains more than 150 species growing in East and Central Africa [6], which are indigenous to tropical South America and the West Indies. Morella salicifolia is a deciduous shrub 3-20 m in height and usually found in humid lower highlands between some 1800 and $3000 \mathrm{~m}$ in altitude with a bark light grey to brown, and often covered with lichen and moss [7]. It was formerly named Myrica salicifolia HOCHST. ex A. RICH. until the genus Myrica was divided into two genera: Myrica and Morella. Then after Myrica salicifolia belongs to the genus Morella, and known with the new name Morella salicifolia (HOCHST. ex

*Corresponding author. E-mail: aman_d00@yahoo.com

This work is licensed under the Creative Commons Attribution 4.0 International License 
A. RICH.) VERDC. \& POLHILL. (syn. Myrica salicifolia HOCHST. ex A. RICH.) [1]. M. salicifolia is distributed mostly in Tanzania, Kenya, Uganda, Rwanda, Burundi, Ethiopia, Democratic Republic of the Congo, Yemen, and Saudi Arabia [8,9].

In Ethiopia M. salicifolia is largely found in Southern Ethiopia (especially in Kambata, Hadya Wolayta and Sidama Zone) and East Hararge zone of Oromia Region (Ejersa Goro). The vernacular names of the species are 'Shinet' or 'Kalawa' in Amharic [10], 'Dadecco' in Affan Oromo [11], 'Gawada' in Kambategna and 'Kowada' in Hadyagna. This plant is also commonly called 'Bayberry' in English. Various traditional medicinal uses of M. salicifolia were reported in Tanzania which include treatment of cough, toothache, decoction, tonic, stomach troubles, skin diseases [11], headaches [12], and opportunistic diseases of human immunodeficiency virus/acquired immune deficiency syndrome such as tuberculosis, chronic diarrhoea, cryptococcal meningitis, and herpes simplex [13]. Additionally, traditional medicinal uses of M. salicifolia have been reported in other countries such as Ethiopia where it is used for the treatment of skin diseases [14], pain, inflammation, and respiratory disorders $[15,16] . M$. salicifolia has been used for the treatment of male sexual impotence and erectile dysfunction [17] in Uganda.

The pulverized young leaves of M. salicifolia, mixed with butter, are used externally to treat skin diseases [11]. A group of species belonging to the same genus Myrica known as 'pedrahume-caá' in Brazil called insulin plants have been used for the treatment of diabetes according to the empirical African and indigenous knowledge that influenced the formation of the Brazilian culture [18]. This group of plants are Myrica sphaerocarpa, Myrica citrifolia, Myrica uniflora, Myrica multiflora, Myrica guianensis, and Myrica speciosa [19, 20]. These plants prefer dry forests and sandy areas, and are often found in open fields reclaiming abandoned areas, and thus is considered by some people to be an invasive weed. The major plant parts such as fruit, barks and leaves are used for medicinal purposes by local people [21].

In Kambata Tambaro zones in Southern Nations, Nationalities, and Peoples' Region (SNNPR) of Ethiopia, we gathered information about its leaves infusion or juice used to treat skin disease and the stem barks of the plants are chewed to treat toothache, headache and as well as stomachache. Similar ethnobotanical information was reported previously about uses of the plant [22]. Previous phytochemical analysis of roots, and leaves extracts of Morella salicifolia indicated the plant has several bioactive class of compounds (Figure 1).

A preliminary phytochemical screening of the methanolic extracts of the stem bark and leaves showed the presence of polyphenols, unsaturated sterols/triterpenes, saponins, glycosides, and carbohydrates [23]. Biological activity studies on M. salicifolia showed that methanolic extract of M. salicifolia stem bark was effective against Bacillus cereus, Neisseria gonorrhoeae, Shigella dysenteriae, and Staphylococcus aureus [23, 24]. Additionally in vivo testing of a methanolic extract of this species in mice showed potent analgesic and antipyretic activity [25].

Apart from its medicinal uses the mature M. salicifolia fruit was used as a source of wax, often for making candles. The foliage of $M$. gale is a traditional insect repellent, used by campers to keep biting insects out of tents. Several species are also grown as ornamental plants in gardens. The fruit of M. rubra is an economically important crop in China, sold fresh, dried, canned, for juice, and for alcoholic beverages. Fruits of Morella species is used to spice beer and snaps in Denmark [26] Application of related herbs for economy include subjection of the crude oil to chemically extracted henna (Lawsonia inermis L.) decreases the asphaltene precipitation which was obtained by IP143 which will have a very important application in oil industry [27]. More over micro-fluid which contains particles of the mulberry leaf can improve sweep efficiency of brine flooding through sandstone core sample from $49 \%$ to $68.6 \%$ original oil in place mainly due to interfacial tension reduction between oil and aqueous phases [28]. The traditional knowledge regarding the usage of this plant is common but the scientific research such as phytochemical and pharmacological investigation report available today to support the traditional medicinal claim is inadequate. So, it is important to further study 
and explore the chemical composition and biological activities of different parts of this plant as its constituents have a potential of use for pharmaceutical industry. Therefore, the present work has been carried out in order to investigate the phytochemical and antimicrobial activities of stem bark of M. salicifolia.

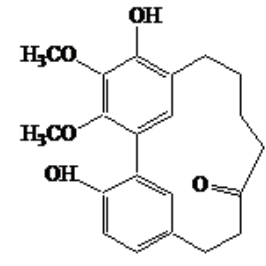

Myricanone

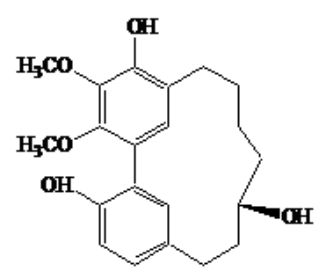

Myricanol

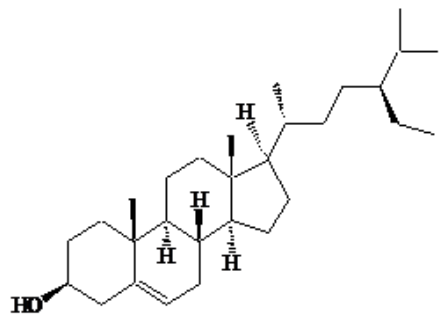

$\beta$--Sitosterol

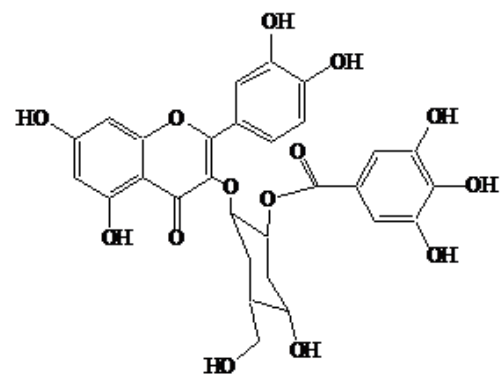

Quercetin

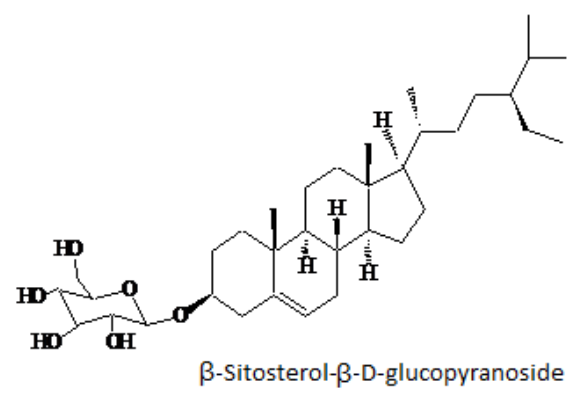

Figure 1. Chemical structures of different class of compounds reported from Morella salicifolia.

\section{EXPERIMENTAL}

\section{Collection and identification of the plant material}

The stem bark of Morella salicifolia was collected from Ejersa Goro, which is located at $44 \mathrm{~km}$ outside the city of Harar in the East Hararghe zone of Oromia Region, Eastern part of Ethiopia, in October 2015. The botanical specimens of the plant were identified and the voucher specimen was deposited at the herbarium of the Department of Plant Science, Haramaya University. After collection, the stem bark sample was washed repetitively with water and air-dried in the shade to make it easily grind able.

\section{Chemicals, reagents and media}

The solvents used in extraction column chromatography including: petroleum ether, methanol, chloroform and ethyl acetate were high performance liquid chromatography (HPLC) grades. The chemicals used were: silica gel S 32-63 $\mu \mathrm{m}$ (230-400 mesh) American Society for Testing and Materials (ASTM) (Germany), solvents (99.9\% methanol HPLC-PLUS grade, 99.8\% chloroform Analytical Reagent New Delhi, India, petroleum ether laboratory reagent and $99.0 \%$ ethyl acetate CDH-Analytical Reagent anhydrous sodium sulfate (Techno pharmchem Delhi, India), 99\% sulfuric acid (Blulux laboratories (P) Ltd., India), potato dextrose agar (PDA) 
(OXOID Ltd.), Mueller Hinton Agar (MHA) (Blulux laboratories (p) Ltd., India), sodium hydroxide pellets AR 98\% (Breckland Scientific Supplies, Thetfolrd Norflok, UK), acetic anhydride ACS-for analysis (British drug house Ltd., UK), Ferric chloride $\left(\mathrm{FeCl}_{3}\right)(\mathrm{British}$ drug house Ltd., England), 37\% hydrochloric acid (Blulux laboratories (P) Ltd., India), Chloramphenicol (Blulux laboratory (p) Ltd., India) and Tilt (Syngenta Crop Protection AG, Basle, Switzerland).

\section{Extraction of the stem bark of Myrica salicifolia}

Soxhlet extraction. The stem bark of the plant was pulverized and sequentially extracted with: petroleum ether, chloroform and chloroform/methanol (1:1) for $8 \mathrm{~h}$ using Soxhlet apparatus.

Hydro-distillation. $60 \mathrm{~g}$ dried stem bark powder of Morella salicifolia was hydro-distilled with $300 \mathrm{~mL}$ of distilled water using Clevenger's apparatus for $3 \mathrm{~h} .100 \mathrm{~mL}$ extract aqueous oil was added to separatory funnel. The oil was extracted and separated from the aqueous layer by adding $50 \mathrm{~mL}$ of chloroform in the separatory funnel three times. The extracted organic layer was collected and dried by adding $5 \mathrm{~g}$ anhydrous sodium sulfate and filtered using Whatman No. 1 filters paper and was concentrated by using rotary evaporator to yield oil. Percentage yield of the essential oil was calculated and the oil was kept at $4{ }^{\circ} \mathrm{C}$ until analysis [29].

$$
\text { Yield of extract }(\%)=\frac{\text { Exract of essential oil in gram }}{\text { Sample of powder in gram }} \times 100
$$

\section{$G C-M S$ analyses}

The essential oils from stem bark of Morella salicifolia were analyzed on GC-MS system consisted of an Agilent Technology Model 7820A using DB-5ms column (30 m x $0.250 \mathrm{~mm}$ internal diameter $\mathrm{x} 0.25 \mu \mathrm{m}$ film thickness) which was coated with $5 \%$ phenyl $95 \%$ methyl poly siloxane as the stationary phase. The syringe was washed with $8 \mu \mathrm{L}$ of chloroform and $2 \mu \mathrm{L}$ of the essential oil solution in chloroform was injected through auto sampler. Column temperature was programmed as follows: 50 to $120^{\circ} \mathrm{C}$ at $20^{\circ} \mathrm{C} / \mathrm{min}, 120$ to $150^{\circ} \mathrm{C}$ at $4{ }^{\circ} \mathrm{C} / \mathrm{min}, 150$ to 250 ${ }^{\circ} \mathrm{C}$ at $20^{\circ} \mathrm{C} / \mathrm{min}$ (with $10 \mathrm{~min}$ hold time) and $3.5 \mathrm{~min}$ solvent delay. The temperature of the injector was fixed to $325^{\circ} \mathrm{C}$ and that of the detector (5977E MSD) to $350{ }^{\circ} \mathrm{C}$. Carrier gas was helium $(1.0 \mathrm{~mL} / \mathrm{min})$ with $69.8 \mathrm{kPa}$ and a split ratio of $1: 250$. The interface temperature was 280 ${ }^{\circ} \mathrm{C}$. The mass spectra were recorded in electron ionization mode at $70 \mathrm{eV}$ with scanning from 40 to $600 \mathrm{~m} / \mathrm{z}$ at 0.5 second and ion source temperature was set at $230^{\circ} \mathrm{C}$. The percentage of each constituent in the oil was determined based on GC peak areas. The constituents of the essential oil were identified by their retention time MH Mass Hunter Library search NIST (National Institute of Standard and Technology) 14 Library and by comparison with mass spectra data available in the literature.

\section{Phytochemical screening}

Qualitative screening of various solvent extracts of stem bark of M. salicifolia was performed for the identification of various classes of active chemical constituents like: alkaloids, tannis, saponins, flavonoids, protein, triterpenoid and terpenod in the plant.

Test for terpenoids: To $0.5 \mathrm{~g}$ of each (petroleum ether, chloroform and chloroform/methanol $1: 1$ ) crude extracts were added $1 \mathrm{~mL}$ of concentrated $\mathrm{H}_{2} \mathrm{SO}_{4}$ and heated for $2 \mathrm{~min}$. Formation of a grayish colour mixture indicates the presence of terpenoids [30].

Test for alkaloids: To $0.5 \mathrm{~g}$ of each (petroleum ether, chloroform and chloroform / methanol $1: 1$ ) crude extracts were added to $1 \mathrm{~mL}$ of Mayer's reagent and few drop of iodine solution. Formation of yellow colour precipitate indicates the presence of alkaloids [31]. 
Test for tannins: To $0.5 \mathrm{~g}$ of each (petroleum ether, chloroform and chloroform/methanol 1:1) crude extracts were added $1 \mathrm{~mL}$ of $\mathrm{FeCl}_{3}$. A blue green or black colored product indicates presence of tannins [32].

Test for saponins: To $0.5 \mathrm{~g}$ of each (petroleum ether, chloroform and chloroform/methanol 1:1) crude extracts were added $2 \mathrm{~mL}$ of distilled water, shaken well and formation of $1 \mathrm{~cm}$ layer of foam indicates presence of saponins [33].

Test for flavonoids: To $0.5 \mathrm{~g}$ of each (petroleum ether, chloroform and chloroform/methanol 1:1) crude extracts were added few fragments of magnesium ribbon and added few drops of concentrated $\mathrm{HCl}$ drop wise. Appearance of pink scarlet colour showed the presence of flavonoids [34].

Test for protein: To $0.5 \mathrm{~g}$ each (petroleum ether, chloroform and chloroform/methanol 1:1) crude extract added few drop of mercuric chloride. Formation of yellow colour mixture indicates the presence of protein [35].

Test for triterpenoids: Qualitative investigation of triterpenoids was followed according to the Libermann Burchard test. $1 \mathrm{~g}$ of each (petroleum ether, chloroform and chloroform/methanol 1:1) crude extracts were treated with $2 \mathrm{ml}$ of acetic anhydride, boiled and cooled, $2 \mathrm{ml}$ concentrated $\mathrm{H}_{2} \mathrm{SO}_{4}$ is added from the side of the test tube. Formation of red colour solution indicated the presence of triterpenoids [36].

Antimicrobial assay

Petroleum ether, chloroform and chloroform/methanol (1:1) extract of stem bark of M. salicifolia and its essential oil were evaluated in vitro for antimicrobial assay by using the paper disc diffusion method. The antimicrobial activities of all samples were performed on four different species of Bacteria that includes two Gram positive bacteria Staphylococcus aureus and Streptococcus agalactiae and two Gram negative bacterium Escherichia coli and Shigela flexneri using MHA medium and the two fungi, Aspergillus niger and Fusarium oxysporum, using PDA medium [37]. All the microbial species were obtained from Plant Pathology Laboratory of the School of Plant Science, Haramaya University. Chloramphenicol was used as standard drug against bacteria whereas tilt was used against fungi.

\section{Preparation of inoculums}

The tested bacterial species were transferred from the stock cultures and streaked on Mueller Hinton Agar (MHA) plates and incubated for $24 \mathrm{~h}$. Well separated bacterial colonies were then used as inoculums. Bacteria were transferred using bacteriological loop to autoclaved MHA that was cooled to about $45^{\circ} \mathrm{C}$ in water bath and mixed by gently swirling the flasks. The medium was then poured to sterile Petri dish, allowed to solidify and used for the biotest. For test fungi, mycelia plugs from stock cultures were transferred to Potato Dextrose Agar (PDA) plates and incubated for 5 days. Then spores of Aspergillus niger were harvested by washing the surface of the colony using $10 \mathrm{ml}$ sterile distilled water and transferred to $250 \mathrm{ml}$ autoclaved PDA cooled to about $45^{\circ} \mathrm{C}$ in water bath. Likewise, mycelium of Aspergillus fumigates were washed with 10 $\mathrm{mL}$ sterile distilled water, macerated in a blender and the mycelia suspension was transferred to $250 \mathrm{~mL}$ autoclaved PDA cooled to about $45^{\circ} \mathrm{C}$ in water bath. The medium containing spore or mycelia suspension was poured to sterile; a plate allowed to solidify and was used for disk diffusion bioassay [38].

\section{Preparation of test solution}

The petroleum ether extract, chloroform crude extract and $\mathrm{CHCl}_{3} / \mathrm{MeOH}$ crude extract were prepared in concentrations of $0.3 \mathrm{~g} / \mathrm{mL}, 0.2 \mathrm{~g} / \mathrm{mL}$ and $0.2 \mathrm{~g} / \mathrm{mL}$ respective solvents. The volatile oil $100 \%$ was used to test antimicrobial activities. 
Testing for antifungal activity

Filter paper discs of $6 \mathrm{~mm}$ is diameter placed in beaker were sterilized in an oven at $180{ }^{\circ} \mathrm{C}$ for 1 $\mathrm{h}$. The crude extract and each of the concentration of the fraction or oil were then pipetted to the sterile paper discs. $10 \mu \mathrm{L}$ and $20 \mu \mathrm{L}$ of the samples were pipetted to the discs in three replications. Tilt is used as a positive control and corresponding solvent is used as a negative control. The paper discs impregnated with the extract solution were then transferred using sterile forceps to potato dextrose agar (PDA) seeded with spore suspension of test fungi as described under inoculums preparation above. The Petri dishes were incubated at $27{ }^{\circ} \mathrm{C}$ for 5 days. All the tests were performed in triplicate. The antifungal activity was evaluated by measuring the zone of inhibition against the tested organisms.

\section{Testing for antibacterial activity}

Sterilized paper discs were transferred to MHA plate's seeded with bacteria and incubated at $37^{\circ} \mathrm{C}$ for $24 \mathrm{~h}$. All the tests were performed in triplicate. The stem bark crude extracts and volatile oil were taken to test the sensitivity towards four bacteria. Chloramphenicol is used as a positive control and corresponding solvent is used as a negative control.

\section{RESULTS AND DISCUSSION}

\section{Yield of Volatile Oil}

Hydro-distillation of the stem bark of M. salicifolia yielded $15.74 \mathrm{~g}(8.74 \%)$ light green oil with pungent, aroma and flavor.

\section{Phytochemical screening tests}

In the present study the qualitative analysis of Morella salicifolia stem bark extracts were carried out for dried stem bark samples. The preliminary phytochemical screening results of petroleum ether, chloroform and chloroform/methanol (1:1) crude extract of stem bark of Morella salicifolia are presented in Table 1. Its petroleum ether extract was found to contain alkaloid, tannins, saponins, flavonoids, protein and triterpenoids. Its chloroform extract has alkaloid, tannins, flavonoids, triterpenoids but saponins and protein were absent. The chloroform/methanol (1:1) extract contains tannins, flavonoids and triterpenoids but alkaloid, saponins and protein were absent. All extracts contain tannins, flavonoids and triterpenoids.

Table 1. Phytochemicals in petroleum ether extract, chloroform crude extract and chloroform /methanol (1:1) crude extracts.

\begin{tabular}{|l|l|c|c|c|}
\hline No & Constituents & Petroleum ether extract & Chloroform extract & Chloroform/methanol extract \\
\hline 1 & Alkaloid & + & + & + \\
\hline 2 & Tannin & + & + & - \\
\hline 3 & Saponins & + & - & + \\
\hline 4 & Flavonoid & + & + & - \\
\hline 5 & Protein & + & - & + \\
\hline 6 & Triterpenoid & + & + & + \\
\hline
\end{tabular}

$+=$ the presence of phytochemical constituents; $-=$ the absence of phytochemical constituents; $-=$ the absence of phytochemical constituents. 
Tannins were reported to exhibit anidiabetic, anti-inflammory, antibacterial and antitumor activities $[39,40]$. Additionally some tannins were able to inhibit HIV replication selectively beside their use as diuretics.

It was reported saponins are used as mild detergents and in intracellular histochemistry staining to allow antibody access intracellular proteins [39, 41]. Medicinally, saponins are used in hypercholesterolemia, hyperglycemia, antioxidant, anti-cancer, anti-inflammatory, central nervous system activities and weight loss [41]. It is also known to have antifungal properties $[39,40]$. Additionally, it was reported that saponins used to stop bleeding, treating wounds and ulcers as it helps red blood cells to precipitate and coagulate [42]. This can be attributed to ability of saponins to bind with glucose and cholesterol molecules.

Saponins are used by the folkloric remedies of Kashmir (India) in treating wounds [43] presumably because of their ability to cause red blood cells coagulation and therefore help in blood clotting, treating wounds and enteric ulcers problems. The ethnobotanical uses of the plant by local people to treat toothache, headache and as well as stomachache might be due to the presence of saponins as one of phytochemicals in the plant stem bark. The plant saponins generally help humans to fight fungal infections, combat microbes and viruses and knock out some tumor cells, particularly lung and blood cancers [44]. Alkaloid help in controlling development system of living organisms plays some metabolic role and have protective property [42]. Alkaloids have been reported from Morella salicifolia and their medicinal values indicated these compounds serve as natural antibiotics, which help the body to fight infections and microbial invasion [45]. Plant with alkaloids have been determined to exhibit analgesic, antispasmoic and antibacterial properties and are used in medicines for reducing headache and fever $[46,47]$. The presence of alkaloids in the stem bark of $M$. salicifolia might be one of the reasons for its traditional medicinal values. Secondary metabolites serve as chemical defense against micro organisms. While phenolic compound and flavonoids are known to possess biological activity such as antibacterial activity, antioxidant, anti-inflammatory, etc [42]. Triterpenoids are mostly found in plant kingdom. They are produced by the plants are secondary metabolites and some of them have a lot of biological activities [48]. Therefore, the phytochemical screening results reveal that the presence of these phytochemical constituents supports the use of Morella salicifolia plant in folklore medications.

Table 2. GC-MS analysis results of Morella salicifolia stem bark volatile oil.

\begin{tabular}{|l|c|c|c|}
\hline Compounds & RT & M.F. & Area (\%) \\
\hline$\alpha$-Pinene & 6.525 & $\mathrm{C}_{10} \mathrm{H}_{16}$ & 2.38 \\
\hline Metaraminol & 7.890 & $\mathrm{C}_{11} \mathrm{H}_{17} \mathrm{NO}_{3}$ & 0.99 \\
\hline$p$-Cymene & 9.600 & $\mathrm{C}_{10} \mathrm{H}_{13}$ & 1.43 \\
\hline Limonene & 9.752 & $\mathrm{C}_{10} \mathrm{H}_{16}$ & 1.89 \\
\hline Amphetamine & 9.856 & $\mathrm{C}_{9} \mathrm{H}_{13} \mathrm{~N}$ & 1.64 \\
\hline Norephedrine & 26.401 & $\mathrm{C}_{9} \mathrm{H}_{13} \mathrm{NO}$ & 1.83 \\
\hline Methyl tetradecanoate & 38.254 & $\mathrm{C}_{15} \mathrm{H}_{30} \mathrm{O}_{2}$ & 10.71 \\
\hline 1,3-Propanediamine & 41.766 & $\mathrm{C}_{3} \mathrm{H}_{10} \mathrm{~N}_{2}$ & 1.30 \\
\hline Cyanoacetyl urea & 44.400 & $\mathrm{C}_{4} \mathrm{H}_{5} \mathrm{~N}_{3} \mathrm{O}_{3}$ & 4.10 \\
\hline Hexadecanoic acid methyl ester & 45.125 & $\mathrm{C}_{17} \mathrm{H}_{34} \mathrm{O}_{2}$ & 29.40 \\
\hline Methyl 10-trans, 12-cis-Octadecadienoate & 50.394 & $\mathrm{C}_{19} \mathrm{H}_{34} \mathrm{O}_{2}$ & 4.85 \\
\hline (Z)-9-Octadecenoic acid methyl ester & 50.601 & $\mathrm{C}_{19} \mathrm{H}_{36} \mathrm{O}_{2}$ & 28.64 \\
\hline Benzene ethanamine & 50.762 & $\mathrm{C}_{8} \mathrm{H}_{11} \mathrm{~N}$ & 2.76 \\
\hline Methyl stearate & 51.419 & $\mathrm{C}_{19} \mathrm{H}_{38} \mathrm{O}_{2}$ & 8.08 \\
\hline Total & & 100.00 \\
\hline
\end{tabular}

RT: Retention time in min; M.F.: Molecular formula. 


\section{GC-MS analysis}

The gas chromatogram of essential oil of the stem bark of the plant showed the presence of 14 compounds and $100.00 \%$ of components of essential oil has been identified (Table 2). It was found that the major constituents of oil were hexadecanoic acid, methyl ester $(29.40 \%)$ (Figure 2), (Z)-9-octadecenoic acids methyl ester (28.64\%) (Figure 2), methyl tetradecanoate $(10.71 \%)$, methyl stearate $(8.08 \%)$, methyl 10-trans, 12 -cis-octadecadienoate $(4.85 \%)$ and cyanoacetyl urea $(4.10 \%)$.
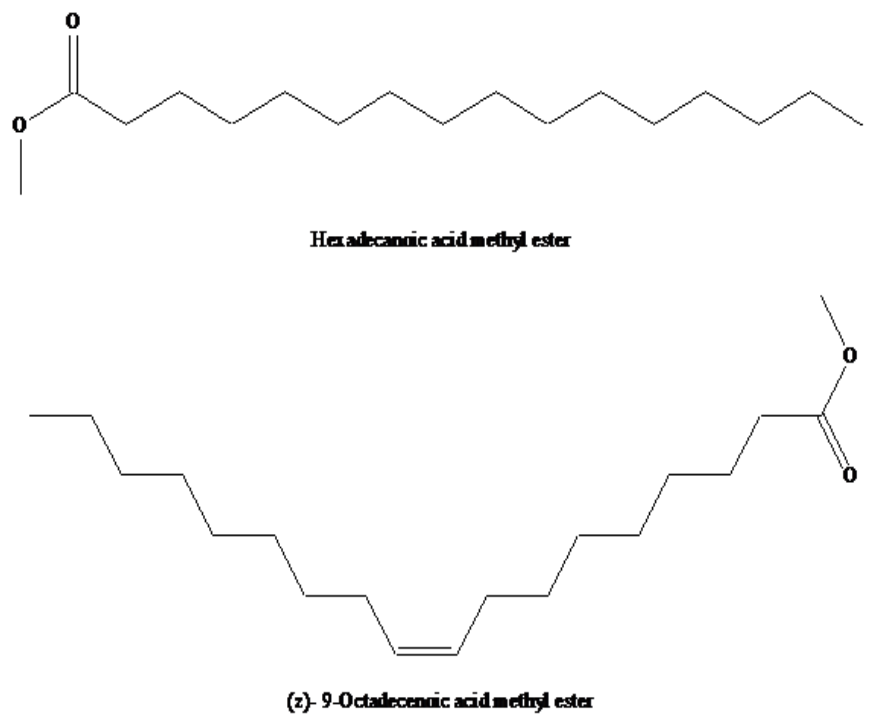

Figure 2. Structures of major compounds identified from volatile oil of stem bark of $M$. Salicifolia.

The hydrolysis product of major fatty acid of hexadecanoic acid, methyl ester is palmitic acid. Palmitic acid possesses antimicrobial and antioxidant properties [49]. Palmitic acid displayed antioxidant properties and can help prevent atherosclerosis in rats [50]. Some of the traditional medicinal values of the plant might be due to enzymatic hydrolysis of hexadecanoic acid, methyl ester identified in the plant.

\section{Analysis of antimicrobial activities}

The volatile oil, crude extracts and their components are known to be active against a wide variety of microorganisms, including Gram-negative and Gram-positive bacteria. The petroleum ether extract, chloroform crude extract and $\mathrm{CHCl}_{3} / \mathrm{MeOH}$ (1:1) crude extracts were significantly active against Staphylococcusaureus, Streptococcus agalactiae, Escherichia coli, and Shigela flexneri at concentration of $20 \mu \mathrm{L}$ and had inhibition zones of above $6.33 \mathrm{~mm}$. The highest activity was exhibited by volatile oil, petroleum ether and $\mathrm{CHCl}_{3} / \mathrm{MeOH}$ (1:1) extract against Streptococcus agalactiae, Shigela flexneri and Escherichia coli with diameter of $21.7 \mathrm{~mm}, 18.0 \mathrm{~mm}$ and $17.7 \mathrm{~mm}$, respectively (Figure 3a-d, Table 3). 
$\mathbf{a}$

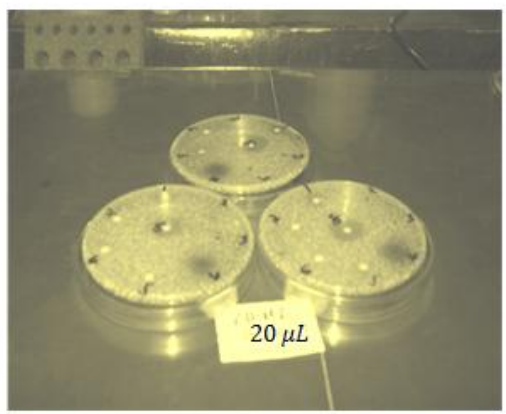

c

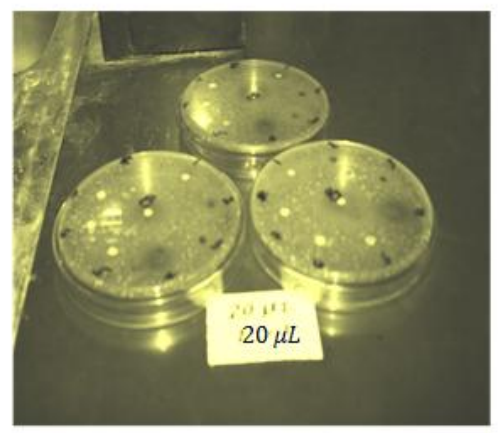

b

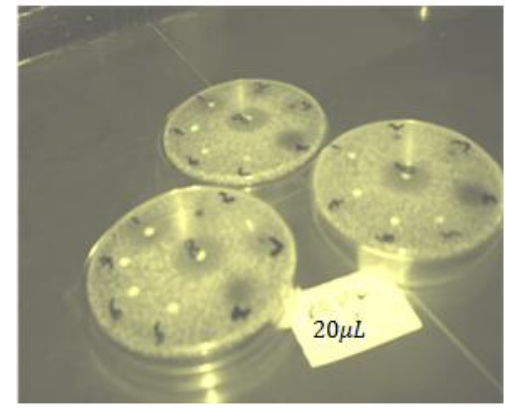

d

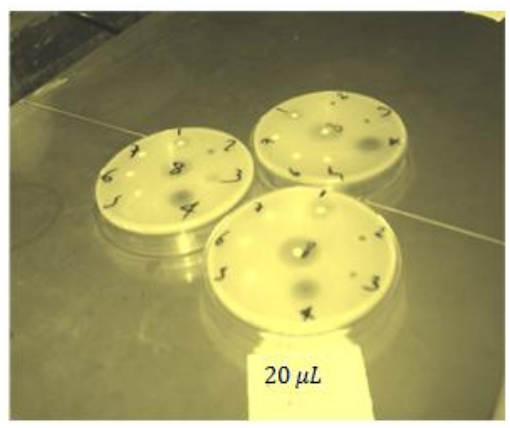

Figure 3. Antibacterial activities of Morella salicifolia stem bark of volatile oil, crude extracts, isolated compounds, fractions, solvent and chloramphenicol: a. Staphylococcus aureus, b. Streptococcus agalactiae, c. Escherichia coli, d. Shigella flex.

The explanation of this activity could be due to high concentration of anti-bacterial compounds in these extracts. There is no inhibition effect on Staphylococcus aureus, Streptococcus agalactiae, and Shigela flexneri for volatile oil, petroleum ether extract and chloroform crude extracts at concentration of $10 \mu \mathrm{l}$ this might be due to low concentration of anti-bacterial activity in the sample. On the other hand, $\mathrm{CHCl}_{3} / \mathrm{MeOH}(1: 1)$ crude extract showed inhibition effect in $10 \mu \mathrm{L}$ concentration on Staphylococcus aureus and Shigela flexneri. All extracts shows inhibition effect at concentration of $10 \mu \mathrm{L}$ and $20 \mu \mathrm{L}$ on Escherichia coli. This result shows the plant is a good candidate for development of anti-bacterial drugs. The commercial standard drug (chloramphenicol), volatile oil and crude extract showed the greatest inhibition effect against both bacteria in both concentrations (10 and $20 \mu \mathrm{L})$, the negative control (chloroform) does not inhibit all bacterial species and it was obtained not to have any effect or contribution to the test solution so that all the measured values are purely for the respected solutes.

Generally Gram-negative bacteria are more resistant to antimicrobial agents compared with Gram-positive bacteria (Table 3) because they are covered with a phospholipid membrane carrying the structural lipopolysaccharide (LPS) component that makes their cell wall impermeable to antibacterial substance [51]. However, the present results revealed that the 
isolated crude extracts are much more active against the Gram-negative bacteria than the Grampositive ones.

Table 3. Zone of bacterial growth inhibition $(\mathrm{mm})$ for volatile oil, petroleum ether, chloroform, and chloroform/methanol (1:1) crude extract of Myrica salicifolia.

\begin{tabular}{|l|c|c|c|c|c|}
\hline Sample & \multirow{2}{*}{$\begin{array}{c}\text { Dose } \\
\mu \mathrm{L}\end{array}$} & \multicolumn{3}{|c|}{ Types of bacteria with mean inhibition diameter (mm) } \\
\cline { 3 - 7 } & & \multicolumn{2}{|c|}{ Gram (+) bacteria } & \multicolumn{2}{c|}{ Gram (-) bacteria } \\
\hline & 10 & - & - & $6.80 \pm 0.09$ & - \\
\hline Volatile oil & 20 & $6.83 \pm 0.22$ & $12.50 \pm 0.59$ & $9.33 \pm 0.06$ & $21.7 \pm 0.12$ \\
\hline \multirow{3}{*}{$\begin{array}{l}\text { Petroleum ether } \\
\text { extract }\end{array}$} & 10 & - & - & $5.83 \pm 0.06$ & - \\
\hline \multirow{2}{*}{$\begin{array}{l}\text { Chloroform crude } \\
\text { extract }\end{array}$} & 20 & - & $18.00 \pm 1.20$ & $9.50 \pm 0.07$ & $20.5 \pm 1.37$ \\
\hline \multirow{2}{*}{$\begin{array}{l}\mathrm{CHCl}_{3} / \mathrm{MeOH}(1: 1) \text { crude } \\
\text { extract }\end{array}$} & 10 & - & - & $7.60 \pm 0.07$ & - \\
\hline \multirow{2}{*}{\begin{tabular}{l} 
Chloroform \\
\cline { 2 - 6 }
\end{tabular}} & 20 & - & $6.33 \pm 0.08$ & $10.67 \pm 0.22$ & $14.8 \pm 0.33$ \\
\cline { 2 - 6 } & 20 & $5.2 \pm 0.04$ & - & $16.17 \pm 0.05$ & $8.00 \pm 0.06$ \\
\hline Chloramphenicol & 10 & - & - & - & - \\
\cline { 2 - 6 } & 20 & - & - & - & - \\
\cline { 2 - 6 } & 10 & $13.80 \pm 0.02$ & $23.2 \pm 0.06$ & $23.00 \pm 0.02$ & $21.0 \pm 0.07$ \\
\cline { 2 - 6 } & 20 & $21.00 \pm 0.39$ & $24.5 \pm 0.07$ & $28.00 \pm 0.11$ & $25.5 \pm 0.07$ \\
\hline
\end{tabular}

Value represents, ZI = Zone of inhibition in mm mean of three replications \pm SD; - stands for no inhibition.
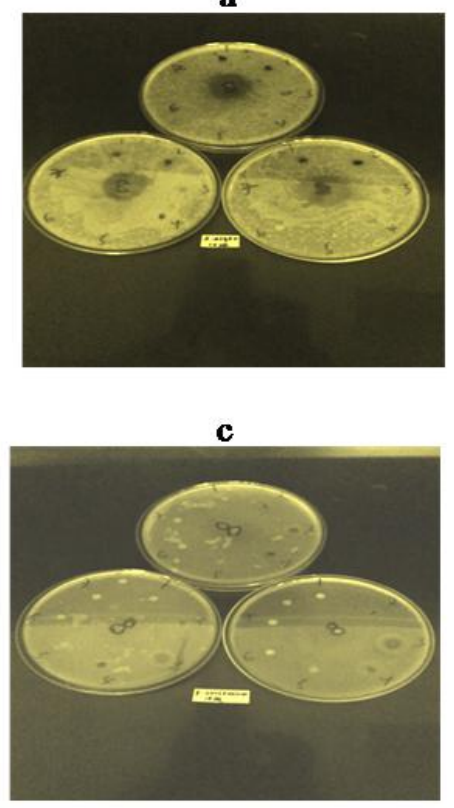

b

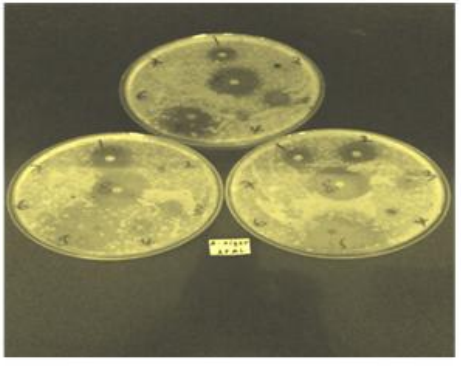

d

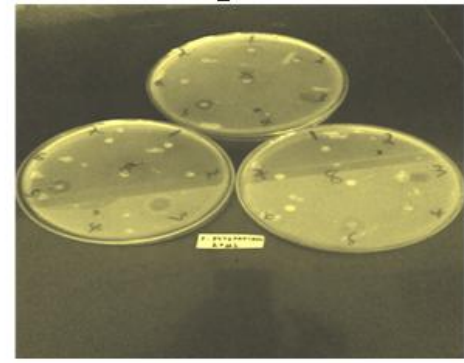

Figure 4. Antifungal activities of Morella salicifolia stem bark of volatile oil, crude extracts, isolated compounds, fractions, solvent and tilt; a. $10 \mu \mathrm{L}$ sample applied on Aspergillus niger, b. $20 \mu \mathrm{L}$ sample applied on Aspergillus niger, c. $10 \mu \mathrm{L}$ sample applied on Fusarium oxysporium, d. $20 \mu \mathrm{L}$ sample applied on Fusarium oxysporium. 
This activity, therefore, could be explained from the chemical nature of the test samples which might affect the overall impermeability and integrity of the bacterial cell wall. Gramnegative bacterium showed more sensitivity to the crude extracts than the Gram-positive bacteria this is because outermost structures of Gram positive and negative bacteria possessing some main differences which affects the mechanisms of antimicrobial resistance [52]. There can be several factors which can affect or reduce the efficacy of the medicinal plants in their antimicrobial activity which includes the time of plant collection the state of plant processing and the state of storage of plant [52]

The fungal species used were Aspergillus niger and Fusarium oxysporum which are known as food spoilage agents. Antifungal activity was studied by using contact assay (in vitro), which results in hyphal growth inhibition. The maximum antifungal activity was shown by petroleum ether extract and chloroform crude extract against the two fungi species Aspergillus niger and Fusarium oxysporum with inhibition zone of $18.33 \mathrm{~mm}$ and $8.67 \mathrm{~mm}$ at $20 \mu \mathrm{L}$, respectively (Figure 4a-d, Table 4). The susceptibility of Aspergillus niger and Fusarium oxysporum for petroleum ether extract and chloroform crude extract demonstrates higher antifungal activities in terms of growth inhibition of the tested organisms.

The minimum antifungal activity was shown by chloroform crude extract against Aspergillus niger with an inhibition zone of $14.00 \mathrm{~mm}$ at $20 \mu \mathrm{L}$ and for volatile oil extract against Fusarium oxysporum with an inhibition zone of $6.33 \mathrm{~mm}$ at $20 \mu \mathrm{L}$.

Table 4. Zone of fungal growth inhibition $(\mathrm{mm})$ for volatile oil, petroleum ether, chloroform, and chloroform/methanol (1:1 ratio) crude extract of stem bark of Myrica salicifolia.

\begin{tabular}{|l|c|c|c|}
\hline Sample & Dose $\mu \mathrm{L}$ & \multicolumn{2}{|c|}{ Types of bacteria with mean inhibition diameter $(\mathrm{mm})$} \\
\hline & & Aspergillus niger & Fusarium oxysporum \\
\hline Volatile oil & 10 & $5.83 \pm 0.06$ & $3.83 \pm 0.30$ \\
\hline & 20 & $17.17 \pm 0.20$ & $6.33 \pm 0.31$ \\
\hline \multirow{2}{*}{$\begin{array}{l}\text { Petroleum ether } \\
\text { extract }\end{array}$} & 10 & $9.00 \pm 0.26$ & - \\
\hline \multirow{2}{*}{$\begin{array}{l}\text { Chloroform crude } \\
\text { extract }\end{array}$} & 20 & $18.33 \pm 0.14$ & - \\
\hline \multirow{2}{*}{$\begin{array}{l}\text { CHCl } \\
\text { extract } \mathrm{MeOH}(1: 1) \text { crude }\end{array}$} & 10 & $5.66 \pm 0.14$ & $6.83 \pm 0.16$ \\
\cline { 2 - 4 } & 20 & $14.00 \pm 0.33$ & $8.67 \pm 0.18$ \\
\cline { 2 - 4 } Chloroform & 10 & - & - \\
\cline { 2 - 4 } & 10 & - & - \\
\hline \multirow{2}{*}{ Tilt } & 20 & - & - \\
\cline { 2 - 4 } & 10 & $10.67 \pm 0.13$ & $10.83 \pm 0.45$ \\
\hline
\end{tabular}

Value represents mean of three replication, $\pm \mathrm{SD}$, - Stands for no inhibition.

Petroleum ether extract showed antifungal activity against Aspergillus niger but did not show activity against Fusarium oxysporum. With exception of $\mathrm{CHCl}_{3} / \mathrm{MeOH}$ (1:1) crude extract, and solvent in the (Table 4 and Figure 4), but all other samples showed different inhibition effect against the tested fungi from doses $10-20 \mu \mathrm{L}$ due to the doses effect. The commercial standard drug (Tilt) showed the greatest inhibition in both cases as anti fungal activity rather than all sample, this drug shows different inhibition effect for both doses (10 and $20 \mu \mathrm{L})$.

\section{CONCLUSION}

Stem bark of Morella salicifolia is used locally for treatment of various diseases. Based on this ethnobotanical information, phytochemical analysis, volatile oil analysis and antimicrobial activity tests of stem bark of $M$. salicifolia were performed and it can be concluded that various 
phytochemicals are present in the stem bark of this plant such as alkaloids, tannins, saponins, flavonoids, protein and triterpenoids. The essential oils of the plant contain mainly fatty acid esters as major compoents. Antimicrobial activity tests showed some antimicrobial potency of the extracts even though it was very lower as compared to standard antibiotics. Volatile oil extract of stem bark of M. salicifolia was active against the four microbial pathogens tested. The $\mathrm{CHCl}_{3} / \mathrm{MeOH}(1: 1)$ crude extract showed the highest degree of antibacterial activity against Staphylococcus aureus, and Escherichia coli as compared to the other extracts.

From the present study we can conclude that this plant contains several phytochemicals, but antimicrobials activities were comparatively lower than that of the standard drug used in the study. The presence of these phytochemicals in this plant stem bark enhances their pharmaceutical, therapeutic potentials and provides scientific support for the ethnomedicinal use of the plant. The present study indicates the plant bark is a potential source of bioactive compounds and can be used as source for antibacterial and antifungal agents.

\section{ACKNOWLEDGEMENTS}

Birhanu Gebriel hearty thanks and appreciate Haramaya University which provided him the chance to pursue his MSc education and made this study possible.

\section{REFERENCES}

1. Ernest, R. Medicinal Plants and Traditional Medicine in Africa: Constraints and Challenges. Conserve Africa International, Nairobi, Kenya. Sustainable Development International, 1999.

2. Houghton, P.J. The role of plants in traditional medicine and current therapy. $J$. Altern. Complement. Med. 1995. 1, 131-143.

3. WHO. Traditiona Medicine Strategy, 2002-2005; WHO/EDM/TRM/2002.1; 2001.

4. Samuelsson, G. Plants used in traditional medicine as sources of drugs. Bull. Chem. Soc. Ethiop. 1987, 1, 47-54.

5. Sujata, G.; Dastidar, A.; Manna, K.; Asok, K.; Kaushiki M.N.K.; Dutta, A.N.; Chakrabarty, N.; Motohashi, Y.S. Studies on the antibacterial potentiality of isoflavones. Int. J. Antimicrob. Agents. 2004. 23, 99-102.

6. Beentje, H.J. Kenya trees, shrubs and lianas natural museums of Kenya: Nairobi; 1994.

7. Sebsbe, D. Myrsinacae in: Flora of Ethiopia and Eritera. Part I. Apiacea to Dipsacaceas. Addis Ababa, Ethiopia, Uppsala, Sweden; 2003; 4, p 64-70.

8. Mbuya, L.P.; Msanga, H.P.; Ruffo, C.K.; Birnie, A.; Tengnas, B. Useful Trees and Shrubs for Tanzania. Identification, Propagation and Management for Agricultural and Pastoral Communities; SIDA Regional Conservation Unit, RSCU: Stockholm, Sweden; 1994.

9. Kokwaro, J. Medicinal Plants of East Africa; Kenya literature Bureau: Nairobi, Kenya; 1976.

10. Amare, G. Some common medicinal and poisonous plants used in Ethiopian folk medicine faculty of science, Addis Ababa University, and Addis Ababa Ethiopia; 1976.

11. Hedberg, I.; Hedberg, O.; Madati, P.J.; Mshigeni, K.E.; Mshiu, E.N.; Samuelsson, G. Inventory of plants used in traditional medicine in Tanzania. II. Plants of the families Dilleniaceae-Opiliaceae. J. Ethnopharmacol. 1983, 9, 106-112.

12. Schlage, C.; Mabula, C.; Mahunnah, R.L.A.; Heinrich, M. Medicinal plants of the Washambaa (Tanzania): Documentation and ethnopharmacological evaluation. Plant Biol. 2000, 2, 83-92.

13. Kisangau, D.P.; Lyaruu, H.V.M.; Hosea, K.M.; Cosam, C.J. Use of traditional medicines in the management of HIV/AIDS opportunistic infections in Tanzania: A case in the Bukoba Rural District. J. Ethnobiol. Ethnomed. 2007, 3, 1-8. 
14. Getahun, A. Some Common Medicinal and Poisonous Plants Used in Ethiopian Folk Medicine; Registrated in the Data Bank Prelude; Amare Getahun: Addis Ababa, Ethiopia, 1976.

15. Teklay, A.; Abera, B.; Giday, M. An ethnobotanical study of medicinal plants used in Kilte Awulaelo District, Tigray Region of Ethiopia. J. Ethnobiol. Ethnomed. 2013, 9, 1-23.

16. Kefalew, A.; Asfaw, Z.; Kelbessa, E. Ethnobotany of medicinal plants in Ada'a District, East Shewa Zone of Oromia Regional State, Ethiopia. J. Ethnobiol. Ethnomed. 2015, 11, 25. DOI: 10.1186/s13002-015-0014-6.

17. Kamatenesi-Mugisha, M.; Oryem-Origa, H. Traditional herbal remedies used in the management of sexual impotence and erectile dysfunction in Western Uganda. Afr. Health Sci. 2005, 5, 40-49.

18. Aguiar, J.P.; Silva, M.D.L.P. Foliar anatomy of pedra-hume-caá (Myrcia sphaerocarpa, Myrcia guianensis, Eugenia punicifolia, Myrtaceae). Acta Amazonica, 2000, 30, 49-49.

19. Matsuda, H.; Morikawa, T.; Yoshikawa, M. Antidiabetogenic constituents from several natural medicines. Pure App. Chem. 2002, 74, 1301-1308.

20. Limberger, R.P.; Sobral, M.E.G.; Henriques, A.T.; Menut, C.; Bessière, J.M. Óleos voláteis de espécies de Myrcia nativas do Rio Grande do Sul. Química nova. São Paulo. 2004, 27, 916-919.

21. Dagne, E. Natural database for Africa (NDA); 2011.

22. Kirtikar, K.R.; Basu, B.D. Indian Medicinal Plants, 2nd ed., International Book Distributors: New Delhi, India; 1999; $\mathrm{p} 3$.

23. Geyid, A.; Abebe, D.; Debella, A.; Makonnen, Z.; Aberra, F.; Teka, F.; Kebede, T.; Urga, K.; Yersaw, K.; Biza, T.; et al. Screening of some medicinal plants of Ethiopia for their antimicrobial properties and chemical profiles. J. Ethnopharmacol. 2005, 97, 421-427.

24. Kilonzo, M.; Ndakidemi, P.A.; Chacha, M. In vitro antifungal and cytotoxicity activities of selected Tanzanian medicinal plants. Trop. J. Pharm. Res. 2016, 15, 2121-2130.

25. Njung'e, K.; Muriuki, G.; Mwangi, J.W.; Kuria, K.A.M. Analgesic and antipyretic effects of Myrica salicifolia (Myricaceae). Phytother. Res. 2002, 16, 73-74.

26. https://en.wikipedia.org/wiki/Myrica, Accessed on March 20, 2019.

27. Monjezi, E.; Rostami, A.; Joonaki, E.; Shadizadeh, S.R. New application of henna extract as an asphaltene inhibitor: an experimental study Asia-Pac. J. Chem. Eng, 2016, 11, $1027-$ 1034.

28. Ahmadi, M.A.; Arabsahebi, Y.; Shadizadeh, S.R.; Behbahani, S.S. Preliminary evaluation of mulberry leaf-derived surfactant on interfacial tension in an oil-aqueous system: EOR application. Fuel 2014, 117, 749-755.

29. Costa, O.B.D.; Menezzi, D.; Soares, C.H.; Benedito, L.E.C.; Resck, I.S.V Vieira, R.F.; Ribeiro Bizzo, H. Essential oil constituents and yields from leaves of Blepharocalyx salicifolius (Kunt) O. Berg and Myracrodruon urundeuva (Allemão) collected during daytime. Inter. J. Forest. Res. 2014, 2014. Article ID 982576, DOI: 10.1155/2014/982576.

30. Sofowora, A. Medicinal Plants and Traditional Medicine in Africa, Spectrum Books Ltd.: Ibadan; 1993, pp 191-289.

31. Kuri, S.; Billah, M.M.; Rana, S.M.; Naim, Z.; Islam, M.M.; Hasanuzzaman, M.; Ali, M.R.; Banik, R. Phytochemical and in vitro biological investigations of methanolic extracts of Enhydra fluctuans Lour. Asian Pac. J. Trop. Biomed. 2014, 4, 299-305.

32. Ayoola, G.A.; Coker, H.A.; Adesegun, S.A.; Adepoju-Bello, A.A.; Obaweya, K.; Ezennia, E.C.; Atangbayila, T.O. Phytochemical screening and antioxidant activities of some selected medicinal plants used for malaria therapy in Southwestern Nigeria. Trop. J. Pharm. Res. 2008, 7, 1019-1024.

33. Dyana, J.P.; Kanchana, G. Preliminary phytochemical screening of Cocos nucifera L. Flowers. Int. J. Curr. Pharm. Res. 2012, 4, 62-63. 
34. Ajuru, M.G.; Williams, L.F.; Ajuru, G. Qualitative and quantitative phytochemical screening of some plants used in ethnomedicine in the Niger Delta region of Nigeria. $J$. Nutr. Food Sci. 2017, 5, 198-205.

35. Albertsen, K.; Christoffersen, N.R.; Heintzelmann, F. The examination of isolated serum proteins by the mercuric chloride and thymol reactions. Acta Med. Scand. 1950, 136, $302-$ 312.

36. Sheel, R.; Nisha, K.; Kumar, J. Preliminary phytochemical screening of methanolic extract of Clerodendron infortunatum. IOSR J. Appl. Chem. 2014, 7, 10-13.

37. Laport, M.S.; Marinho, P.R.; da Silva Santos, O.C.; de Almeida, P.; Romanos, M.T.V.; Muricy, G.; Brito, M.A.V.P.; Giambiagi-deMarval, M., Antimicrobial activity of marine sponges against coagulase-negative staphylococci isolated from bovine mastitis. Vet. Microbiol. 2012, 155, 362-368.

38. Ogunniran, K.O. Antibacterial effects of extracts of Ocimum gratissimum and piper guineense on Escherichia coli and Staphylococcus aureus. Afr. J. Food Sci. 2009, 3, 77-81.

39. Maobe, M.A.; Gatebe, E.; Gitu, L.; Rotich, H. Preliminary phytochemical screening of eight selected medicinal herbs used for the treatment of diabetes, malaria and pneumonia in Kisii region, southwest Kenya. Eur. J. App. Sci. 2013, 5, 01-06.

40. Argal, A.; Pathak A.K. CNS activity of Calotropis gigantea roots. J. Ethnopharm. 2006, $106,142-145$

41. Malairajan, P.; Geetha, G.; Narasimhan, S.; JessiKala Veni, K. Analgesic activity of some Indian medicinal plants. J. Ethnopharm. 2006, 19, 425-428.

42. Thamaraiselvi, P.; Jayanthi, P. Preliminary studies on phytochemicals and antimicrobial activity of solvent extracts of Eichhornia crassipes (Mart.) Solms. Asian J. Plant Sci. Res. 2012, 2, 115-122.

43. Foster, S.; Duke, J.A. A Field Guide to Medicinal Plants and Herbs of Eastern and Central North America, Vol. 2, Houghton Mifflin Harcourt, Online Publication; 2000.

44. Poornima, G.N.; Ravishankar, R.V. Evaluation of phytonutrients and vitamin contents in a wild yam, Dioscorea belophylla (Prain) Haines. Afr. J. Biotechnol. 2009, 8, 971-973.

45. Sodipo, O.A.; Akiniyi, J.A.; Ogunbamosu, J.U. Studies on certain characteristics of extracts of bark of Pansinystalia macruceras (K Schemp) Pierre Exbeille. Global J. Pure Appl. Sci 2000, 6, 83-87.

46. Patra, J.K.; Mohanta, Y.K. Antimicrobial compounds from Mangrove plants: A pharmaceutical prospective. Chin. J. Integr. Med. 2014, 20, 311-320.

47. Wadood, A.; Ghufran, M.; Jamal, S.B.; Naeem, M.; Khan, A.; Ghaffar, R. Phytochemical analysis of medicinal plants occurring in local area of Mardan. Biochem. Anal. Biochem. 2013, 2, 1-4.

48. Hanson, J.R. Natural Products: The Secondary Metabolites, Vol. 17, Royal Society of Chemistry: Cambridge, UK; 2003, pp 112-121.

49. Mujeeb, F.; Bajpai, P.; Pathak, N. Phytochemical evaluation, antimicrobial activity, and determination of bioactive components from leaves of Aegle marmelos. Biomed. Res. Int. 2014, 2014, Article ID 497606, DOI: 10.1155/2014/497606.

50. http://www.livestrong.com/article/521518-palmitic-acid-health-benefits/; Accessed on March 20, 2019.

51. Patrone, J.B.; Stein, D.C. Effect of gonococcal lipooligosaccharide variation on human monocytic cytokine profile. BMC Microbiol. 2007, 7, 7.

52. Griggs, J.K.; Towers, G.H.N.; Taylor, R.S.L. The effects of storage on the biological activity of medicinal plants from Nepal. J. Ethnopharm. 2001, 77, 247-252. 